\title{
LIABILITY FOR VIOLATION OF QUARANTINE: NOVELTIES OF ADMINISTRATIVE AND CRIMINAL LEGISLATION
}

RESPONSABILIDAD POR VIOLACIÓN DE CUARENTENA: NOVEDADES DE LA LEGISLACIÓN ADMINISTRATIVA Y PENAL

\author{
Sergii Starodubov* \\ Viktoriia Vladyshevska** \\ Maryna Pyzhova***
}

\begin{abstract}
Public legislation has long failed to meet such large-scale challenges as the SARS-CoV-2 pandemic. In emergencies, to protect the lives and health of the population, it is necessary to promptly make decisions on the legal regulation of public relations that have developed due to the spread of Covid-19. For this purpose, the state has created legal mechanisms that are designed to ensure compliance with the rule of law and which need the scientific-legal assessment. The objective of the work is to analyze the novelties of administrative and criminal legislation, which regulate the liability for violation of quarantine. The object of research is the norms of administrative and criminal law. The subject of the study is public relations that have developed as a result of the introduction of quarantine and which are governed by administrative and criminal law. To achieve this goal, the
\end{abstract}

\footnotetext{
* Ph.D., Acting Dean of the Faculty of Prosecutor's Office and Investigation (Criminal Justice), Associate Professor of Criminal Procedure of National "Odesa Law Academy," Odesa (Ukraine). https://orcid.org/0000-0003-2328-1063. svstar2705@ukr.net

** Ph.D., Assistant of Department of Judiciary, Law Enforcement Authorities and Advocacy, National University "Odesa Law Academy," Odesa (Ukraine). https://orcid.org/0000-0001-9666-5995. viktoriia.vladyshevska@onua.edu.ua

*** Ph.D., Associate Professor of the Department of Legal Sciences of the Institute of Management and Law of Yaroslav Mudryi National Law University, Kharkiv (Ukraine). https://orcid.org/0000-0003-3652-5581. pyzhova91@ gmail.com
} 
situation in foreign countries was firstly analyzed; general patterns were identified; alternative solutions were proposed, with a minimum restriction of human rights and freedoms. Then, the novelties of the national legislation were studied in more detail; additional specific problems were identified; and a more balanced legislative policy was proposed. As a result of the study, the current state of legal regulation in the areas of administrative and criminal law related to quarantine violations was analyzed; the liability for such offenses was characterized; some conclusions regarding the existing related problems were made and options for their solution were proposed, as well as propositions for modernization of legislation were made.

Keywords: Coronavirus, Quarantine, Offense, Liability, Fine

Resumen: La legislación pública no ha logrado enfrentar desafíos a gran escala como pandemia del SARS-CoV-2. En emergencias, para proteger la vida y la salud de la población, es necesario regular pronto las cuestiones desarrolladas debido a la propagación del Covid-19. Para ello, el estado ha creado algunos mecanismos para asegurar el cumplimiento del estado de derecho y que necesitan la valoración científico-legal. El propósito del trabajo es analizar las novedades de la legislación administrativa y penal, que regulan la responsabilidad por violación de la cuarentena. El objeto de la investigación son las normas del derecho administrativo y penal. El tema del estudio son las relaciones públicas que se han desarrollado como resultado de la introducción de la cuarentena y que se rigen por el derecho administrativo y penal. Para lograr este objetivo, se analizó en primer lugar la regulación en el derecho comparado; se identificaron patrones generales; se propusieron soluciones alternativas, con una mínima restricción de los derechos humanos y las libertades. Luego, se estudiaron con más detalle las novedades de la legislación nacional; se identificaron problemas específicos adicionales; y se propuso una política legislativa más equilibrada. Como resultado del estudio, se analizó el estado actual de la regulación legal en las áreas de derecho administrativo y penal relacionados con las infracciones de cuarentena; la responsabilidad caracterizada por tales delitos; y se sacaron conclusiones sobre los problemas existentes, además de proponer algunas soluciones que pueden modernizar la legislación.

Palabras clave: Coronavirus, Cuarentena, Delito, Responsabilidad, Multa 
Summary. I. Introduction. II. Methodology. III. Analysis of recent research. Iv. Results and discussion. IV.1. international experience in imposing sanctions for quarantine violations. IV.2. National legislation on the implementation of sanctions for quarantine violations. $V$. Conclusions. References.

\section{INTRODUCTION}

Article 11 of the Universal Declaration of Human Rights (1948) sets out the guidelines for criminal liability. In particular, the presumption of innocence is affirmed: no one can be found guilty of a crime until his guilt is established in a public court hearing, if all possibilities for defense are provided. Article 29 of this document allows the restriction of the rights and freedoms specified in the treaty, only to ensure the rights and freedoms of others, respect for morals, public order, and the welfare of a democratic society.

The European Convention on Human Rights (1950) establishes several rules that are extremely important for addressing issues related to liability in criminal and administrative matters. In particular, according to Art. 6 of the Convention, everyone is guaranteed the right to a fair and public hearing within a reasonable time by an independent and impartial tribunal established by law, which will determine the merits of any criminal charge. Article 7 of the mentioned Convention approves the principle of legal certainty of punishment for a committed crime. Article 15 of this international treaty states that in a state of emergency threatening the life of the nation, any signatory State may take measures derogating from its obligations under the Convention, but only to the extent and subject to that, such measures do not conflict with its other international legal obligations (Arakelyan, 2020; Tulyakov, 2020; European Court of Human Rights, 2020).

The presumption of innocence is reflected in national law, in particular in Art. 62 of the Constitution of Ukraine (1996), art. 2 of the Criminal Code of Ukraine (hereinafter, "Criminal Code") (2002). It serves not only as a guarantee of respect for human rights in criminal proceedings but also serves as a fundamental principle of the criminal law field in general.

The principle of legality of measures of influence is contained in Part 1 of Art. 7 of the Code of Ukraine on Administrative Offenses (1984) (hereinafter, "Code on Administrative Offenses"). According to this principle, no one may be subjected to a measure of influence in connection with an administrative offense other than on the grounds and in the manner prescribed by law. 
At the end of 2019, an outbreak of acute respiratory disease Covid-19 caused by a new coronavirus (SARS COV-2) occurred in Wuhan, Hubei Province, China. The rapid spread of the new disease led to the fact that on March 11, 2020, the WHO declared a pandemic. Accordingly, the Resolution of the Cabinet of Ministers of Ukraine $\mathrm{n}^{\circ} 211$ and 392, established quarantine throughout Ukraine from March 12. At the time of writing, according to this resolution, it has been extended until July 31, 2020.

The basics of the legislation of Ukraine on health care establish the obligation of the state and society to take care of health care, affirm the inalienability and inviolability of the natural human right to health care. Article 80 of this Resolution $\mathrm{n}^{\circ} 211$ establishes the possibility of administrative and criminal liability for its violation. The Law of Ukraine "On Ensuring Sanitary and Epidemic Welfare of the Population" (1994) establishes the rights and responsibilities of individuals and legal entities, as well as authorities and local governments related to ensuring the proper level of sanitary and epidemic status of the environment, jobs and public places.

The Law of Ukraine "On Protection of the Population from Infectious Diseases" (2020) is relevant in the context of legal regulation of mechanisms for counteracting the spread of infectious diseases, including acute respiratory disease Covid-19. Article 29 of this legal act regulates the mechanism of quarantine on the territory of Ukraine.

In order to prevent the occurrence and spread of coronavirus disease (Covid-19), Verkhovna Rada adopted the Law n ${ }^{\circ}$ 530-IX of March 17, 2020, which amended the Code on Administrative Offenses and the Criminal Code, thus increasing the responsibility for violating quarantine conditions.

\section{METHODOLOGY}

In studying the subject of research using various methods, including the dialectical method, the system method, formal-legal method, structural method, and comparative-legal method.

To begin with, the dialectical method was used for a comprehensive, complete, thorough analysis of the research topic to determine the truth at a particular point in time and space, in particular, weeding out erroneous judgments about the legal settlement of public law novelties related to Coronavirus, by resolving controversies related to problems of such legal regulation. Meanwhile, the system method was used to depict anticoronavirus innovations in the fields of administrative and criminal law in their interconnectedness, mutual influence, and interaction with objectively existing realities and changes in the multiverse of human life. 
Next, the formal-legal method was used to formulate the features and properties of legal norms, which they enshrine in law, including articles of the Code on Administrative Offenses and the Criminal Code, which relate to liability for violation of quarantine restrictions.

To identify the components of legal norms such as hypothesis, disposition, sanction, as well as the places of articles in which they are listed in the structure of regulations, the structural method was used.

Lastly, to characterize the special features of the novelties of administrative and criminal legislation on liability for violation of quarantine, as well as their differences from other rules of legal regulation, a comparative-legal method was used.

\section{ANALYSIS OF RECENT RESEARCH}

The subject of research due to its relevance began to attract the attention of both theorists and practitioners of jurisprudence. Thus, among scholars and legal practitioners who have analyzed the issues of novelties in the field of public law related to the legal regulation of liability for quarantine violations, we can distinguish the names of Kuzembayev (2020), Khimchenko and Thales (2020), Maslova (2020), Novikova (2020), Nechval (2020), Kolos and Derkach (2020), Klochkov and Starosta (2020), Dovgal (2020).

On the works of Kuzembayev (2020), it is emphasized that the existence of blanket norms in criminal law is a reasonable and justified mechanism that can help in qualifying the infection of others with coronavirus infection as an incurable disease, and therefore, Art. 130 of the Criminal Code "Infection with human immunodeficiency virus or other incurable infectious diseases" may apply.

Khimchenko and Thales (2020) formulate and characterize the composition of the crime. In particular they draw attention to the special subject of the crime. As a result, it is concluded that it is debatable to prosecute for violating quarantine restrictions based on Art. 325 Code on Administrative Offenses.

In her work, Maslova (2020) clarified the responsibility for violating quarantine from the point of view of administrative law. Therefore, the characteristic of the norm is contained in Art. 44-3 of the Code on Administrative Offenses, and also its application on materials of judicial practice is illustrated. As a result, the study concludes that amendments to administrative legislation affected by the Covid-19 pandemic can be 
considered justified, as well as the need to further develop of legal regulation and public information on this issue.

Additionally, Novikova (2020) criticizes the effectiveness of the mechanism of criminal liability for violation of anti-epidemic, sanitaryhygienic, sanitary-epidemiological quarantine measures to combat the spread of acute respiratory disease Covid-19 caused by the new Coronavirus SARS-CoV-2. In particular, attention is focused on the validity of the rule, which as of June 18,2020, has expired, which in turn makes it impossible to prosecute for the changes adopted three months earlier to Art. 325 of the Criminal Code, as the return to the old version, means the retroactive effect of the more lenient law on criminal liability. Based on this, it is concluded that the norm is ineffective in the so-called "Coronavirus" edition and prosecution based on the above article will also be ineffective in the future.

Furthermore, Nechval (2020), in his article draws attention to the procedural difficulties that arise in the qualification of violation of quarantine restrictions under Art. 44-3 of the Code on Administrative Offenses. In particular, there are examples of procedural errors that result in the release of a person from liability and the closure of proceedings based on the impossibility of establishing all its circumstances. In general, it is concluded that the innovations are positive in terms of the objective need to introduce measures aimed at protecting public health and public order, with a caveat about the need to improve the legal regulation of liability for violations of quarantine restrictions.

In their publication, Kolos and Derkach (2020) comprehensively approached the problems related to the responsibility for quarantine violations in the context of the Covid-19 pandemic. Therefore, it is emphasized the danger of expanding the discretionary powers of the subjects entitled to draw up administrative protocols to establish the grounds for the application of Art. 44-3 of the Code on Administrative Offenses while ambiguous interpretation of the objective side of the offense under this article, as well as the vagueness of the relationship between general and special rules in the context of a comparative analysis of Arts. 42 and 44-3 of the Code on Administrative Offenses, which may pose a threat of corruption. Regarding criminal liability for the so-called "Coronavirus" edition of Art. 325 of the Criminal Code, it is noted that it contains such significant legal shortcomings as inconsistency with the principle of legal certainty, the actual duplication of administrative sanctions, a complex procedure for proving causation in court, which calls into question the effectiveness of this criminal rule or its fair application under the rule of law.

Meanwhile, Klochkov and Starosta (2020), in their analytical report support the skeptical attitude about the effectiveness of the norm on criminal 
liability for the spread of coronavirus infection. They also considered the mechanisms of application of administrative liability for violation of quarantine, provided an assessment of the prospects for its application in court. At the same time, Dovgal (2020) on the examples of judicial practice illustrates the application of Art. 325 of the Criminal Code in the "prepandemic" version. It is noted that the number of cases in this category was small and, in most cases, related to violations of food norms and rules of sanitary and hygienic control, which led to the intoxication of consumers with manufactured products or goods.

Among foreign colleagues, I would like to note Londoño Martinez (2020) and his strong works on the topic of limitations on human rights and the use of criminal liability to combat the pandemic. The heated debate in Chilean society about the criminal nature of curfews, economic restrictions, and other quarantine measures reached Congress. The author considers all points of view and explains the resulting gap between the legislator, law enforcement officers, and the rest of the people, and offers soft ways to resolve the conflict. Chile's experience can be very useful to the rest of the countries because as we will see later, the problem of protecting human rights during a pandemic has become global.

Despite the fairly good existing doctrinal base and operational elaboration of details in the context of the legislator's novelties from the scientific community, there are still several questions regarding gaps and inconsistencies concerning laws and their implementation, as well as practical recommendations for the legislator and law enforcement agencies, which we will consider in this article.

\section{RESULTS AND DISCUSSION}

\section{IV.1. International Experience in Imposing Sanctions for Quarantine Violations}

Under the influence of the coronavirus pandemic, quarantine restrictions have been reflected in the legal regulation of most countries. Of course, depending on the initial conditions of the spread and the severity of the threat, the measures taken vary according to the scale and severity of the penalties. Consider the main examples with the caveat that the size and limits of sanctions for violating quarantine abroad may change as the epidemiological situation improves or worsens.

We are all accustomed to hearing terms like "quarantine," "isolation," and "social distancing." Sometimes, they are interchanged, which is not 
correct. Even though these measures pursue the same goal- to slow down the transmission of diseases - they are different in nature:

(i) Isolation is the separation of patients to prevent or limit further transmission of infection.

(ii) Quarantine is the restriction of the movement of healthy people who may be carriers of the virus, usually for the period of incubation until symptoms or a positive test for the disease appear (after which they will be isolated).

(iii) Social distancing is a range of actions, varying from collective to individual behavior, aimed at reducing contact between people-this includes actions such as closing schools, banning large gatherings, and encouraging people to increase their physical distance from each other.

(iv) Lockdown is a colloquial term for some or all of the previous terms but is usually understood as a legal regime severely restricting the movement of citizens.

Since China imposed a quarantine in Hubei province in January 2020, many other states have followed suit by imposing certain quarantine and/or social distancing measures. These actions range from issuing general guidelines and rules advising people to restrict social interaction to strict binding orders for confinement at home. Measures have been taken both in large geographic areas (for example, China's massive quarantine for 57 million people in Hubei province) and in smaller ones (for example, the "containment zone" in New Rochelle, New York, in the USA). In the United States, quarantine measures of varying degrees of strictness covered 200 million people in 21 states (Mervosh, Lu \& Swales, 2020).

As a result, to comply with quarantine measures, many states have turned to criminal law to enforce some of these public health measures in their response to Covid-19.

Thus, the most severe measures of influence for violating quarantine conditions were introduced by the Chinese government: imprisonment for up to ten years, and for those infected for refusing treatment, isolation, infecting others, the death penalty (Ukrinform, 2020).

The experience of Italy shows that moderate fines are not enough to encourage quarantine restrictions - the responsibility increased abruptly as the situation worsened. In total, as of April 1, 2020, in Italy, a person with a confirmed SARS-CoV-2 infection was threatened with a fine of 4,000 euros or imprisonment for one to five years in case of a quarantine violation. There were also sanctions for violating curfews, being on the street without an explanatory note, leaving the boundaries of the place of residence without urgency, and only on receipt of personal responsibility. The consequences of non-compliance with quarantine also include a 30-day ban on "any 
activity," as well as confiscation of the vehicle. The consequences were not long in coming, and more than 40,000 people were charged by the authorities with violating quarantine rules (Tondo, 2020).

In Germany, the legal basis for liability for violation of quarantine conditions is the law on protection against infectious diseases. It is based on this legal act that restrictions on the rights of individuals related to freedom of movement, public assembly, or personal inviolability are possible. Persons who have become ill or have reasonable grounds to believe that they have been infected with the Coronavirus should undergo 14 days of selfisolation at home. In the case of deteriorating health, hospitalization is provided. The amount of the fine provided by German criminal liability laws is calculated by the court taking into account the level of material security of the guilty person, which can range from 150 to 25,000 euros in fines. Imprisonment for up to two years is also envisaged. In the case of infection of another person with Coronavirus as a result of a deliberate violation of quarantine restrictions in Germany, criminal liability in the form of imprisonment for up to five years is provided (Perepadia, 2020).

Finland and Lithuania will not apply expulsions and administrative penalties to foreign nationals whose legal stay has expired during the pandemic and who have not been able to leave their territory voluntarily. In Lithuania, fines are imposed for violating quarantine conditions: from 500 to 1,500 euros for individuals; from 1500 to 6000 euros for legal entities (Chizhik, 2020).

In Turkey, a fine of USD 130 is imposed for violating the requirements for wearing protective masks.

The Israeli authorities have also taken strict measures, even against ultra-religious communities. Similar to the world practice of counteracting the spread of Coronavirus, it was forbidden to move more than $100 \mathrm{~m}$ from the place of residence (Dmytruk, 2020). As a result, there are 86 criminal cases in the first month of the restrictions (Ron, 2020).

In the United Arab Emirates, which has introduced a 14-day quarantine for anyone entering the country, the attorney general noted that those who violate quarantine requirements are committing a "punishable crime" (Turak, 2020).

In Qatar, fines for violating quarantine restrictions or burying rules in a Covid-19 pandemic are up to USD 55,000. Imprisonment for up to three years is also provided (Word and Deed, How to fine for violating quarantine rules in Ukraine and other countries, 2020).

The Indian authorities, by imposing quarantine, provided administrative penalties for violations, the amount and limits of which vary 
from state to state, as well as imprisonment for a term of one to three years (Navrotska, 2020).

Since tightening community quarantines in the Philippines (in midMarch), police have arrested hundreds of people on a variety of charges, including quarantine violations and social distancing measures.

Likewise, Argentina announced that anyone who fails to comply with mandatory isolation or quarantine rules will face a prison sentence from six months to two years (Alcoba, 2020).

Thus, we can see that across the globe, states have used criminal law and the power of law enforcement agencies. But when countries use criminal law, as they do now in their response to Covid-19, they are using the most brutal tool at their disposal. History recalls that when emergency powers are introduced in connection with situations that qualify as "emergencies that threaten the life of the nation" (good faith or bad faith is another matter), they have an odd way of penetrating the usual legal and political framework. So, from the latest examples, we can recall the 2001 Patriotic Act in the United States, which endowed the special services with a wide range of powers, including wiretapping of all citizens of the country, in the name of the good goal of combating terrorism. The act was canceled only in 2015 in connection with numerous scandals of published leaks. In the same 2015, France has already introduced emergency measures in response to the terrorist attacks in Paris - now these measures are reflected in national legislation permanently. Thus, emergency powers are normalized.

In the context of criminal justice and public health, the abuse and overuse of criminal law in public health emergencies set an alarming precedent for how criminal law can be used after the crisis has subsided.

The role of criminal law in enforcing public health measures should be limited based on scientific evidence and respect for human rights. Tuberculosis is a similar area from which valuable lessons can be learned in assessing the feasibility of using criminal law to enforce public health responses to Covid-19 (Sun \& Zilli, 2020).

Although tuberculosis is a serious contagious disease, it can be cured if it is detected and treated promptly. However, it may be necessary to isolate a person with open tuberculosis to prevent further transmission. Effective responses to tuberculosis, like other communicable diseases, depend on voluntary and informed decision-making for prevention, treatment, and care. In most cases, people with open-ended tuberculosis voluntarily adhere to treatment. Even for people who were initially reluctant to accept isolation, patient involvement, counseling, and social support usually resolve the situation positively. 
International health and human rights standards warn that, in most circumstances, forced isolation "violates the human rights to freedom of movement, freedom of association, and freedom from arbitrary detention." However, public health and human rights standards take into account the rare occasions when involuntary isolation and treatment of people with tuberculosis is required. In cases where people with tuberculosis do not adhere to treatment, the World Health Organization (2017) said, «either they are unwilling or unable to comply with infection control measures (...) the interests of other members of the community may justify efforts to force isolation of the patient.»

But according to international human rights norms and standards, as reflected in the Siracusa Principles on the Limitation and Derogation of Provisions in the International Covenant on Civil and Political Rights (1985), deprivation of liberty should be:

- provided for and implemented only under the law;

- aimed at achieving a legitimate aim (with due regard to World Health Organization recommendations when public health is a legitimate aim);

- extremely necessary;

- the least severe and restrictive means should be used;

- be not arbitrary and non-discriminatory in the application;

- limited in duration; and,

- subject to review, including by the judicial authority.

We believe these same standards should apply to the use of criminal law to enforce public health measures related to Covid-19. Communitybased measures, such as appropriate human rights-based quarantines and social distancing measures, may be more effective in complying with public health responses to Covid-19 than the threat of criminal sanctions. Clear, transparent, and consistent public health communications can help convince people to comply with public health measures. The provision of supportive services, meeting basic needs (e.g. food, water), and financial, social, and psychosocial support can also contribute to compliance. Moreover, if sanctions are required to address the consequences of non-compliance, states may primarily use administrative fines, provided they are applied in a manner that is consistent with human rights.

In summary, instead of focusing on criminal measures, countries should focus on taking effective, evidence-based, and human rights-based responses to Covid-19. This includes: 
- the transparent and efficient functioning of public health;

- extensive, accessible testing;

- material and psychological support, especially for vulnerable or marginalized groups of the population; and, as a last resort; and,

- involuntary isolation and quarantine measures, combined with due process safeguards to ensure compliance with international law.

The key point is that there are no exceptions to the pandemic in terms of respect, protection, and observance of human rights.

\section{IV.2. National Legislation on the Implementation of Sanctions for Quarantine Violations}

The Law of Ukraine $n^{\circ}$ 530-IX of March 17, 2020, amended the Criminal Code and the Code of Ukraine on Administrative Offenses. In particular, criminal liability under Art. 325 of the Criminal Code and the Code on Administrative Offenses were supplemented by Art. 44-3 "Violation of the rules on quarantine of people" of the following content: "Violation of the rules on quarantine of people, sanitary and hygienic, sanitary and anti-epidemic rules and regulations provided by the Law of Ukraine "On protection of the population from infectious diseases," other legislation local governments on the fight against infectious diseases, entails the imposition of a fine on citizens from one to two thousand non-taxable minimum incomes and officials - from two to ten thousand non-taxable minimum incomes of citizens," which at the time of writing is from 17,000 to $34,000 \mathrm{UAH}$ for citizens, and from 34,000 to $170,000 \mathrm{UAH}$ for officials (Lisova, 2020).

So, first, consider the novella of administrative liability. The norm of Art. 44-3 of the Code on Administrative Offenses is blanket by its legal nature, which means that the conditions under which liability arises under this article are detailed in other regulations to which it refers.

One of them is the Law of Ukraine "On Protection of the population from infectious diseases" (2020), which defines the concept of quarantine. According to Art. 1, quarantine is "administrative and health measures used to prevent the spread of particularly dangerous infectious diseases." Art. 29 of this source of legal regulation specifies the conditions for the introduction of quarantine in Ukraine. In particular, the authority of the Cabinet of Ministers to impose quarantine on the territory of Ukraine is established; the grounds, limits, and necessary measures related to this are established.

Acts of a normative nature are issued by the Cabinet of Ministers of Ukraine in the form of resolutions, following Part 2 of Art. 49 of the Law of 
Ukraine "On the Cabinet of Ministers of Ukraine" (2014). Article 117 of the Criminal Code states that such resolutions are binding. Given the above, on March 11, 2020, the Cabinet of Ministers of Ukraine adopted Resolution $\mathrm{n}^{\circ}$ 211 "On prevention of the spread of acute respiratory disease Covid-19 caused by the coronavirus SARS-CoV-2," according to which quarantine was established throughout Ukraine.

Thus, the various legislative acts are interrelated in the qualification of the offense under Art. 44-3 of the Code on Administrative Offenses "Violation of rules concerning the quarantine of people."

As for the basis of administrative liability, there is a question of interpretation of the disposition of Art. 44-3 of the Code on Administrative Offenses in this part. Since Art. 42 of the Code on Administrative Offenses "Violation of sanitary norms," the sanctions of which provide significantly lower fines for violations (from 17 to 340 UAH for citizens, and from 102 to $425 \mathrm{UAH}$ for officials), also applies to violations of sanitary rules and regulations, but without mention quarantine, it is not entirely clear whether the sanction of Art. 44-3 of the Code on Administrative Offenses is applied in case of violation of the general sanitary and hygienic rules and norms if they do not concern measures of struggle against infectious diseases, including Covid-19, which are provided by law.

Assuming that the rules of Art. 42 and 44-3 of the Code on Administrative Offenses are correlated as general and special, it seems reasonable to apply the sanction of Art. 42 of the Code on Administrative Offenses in case of violation of the general sanitary rules and norms, and Art. 44-3 of the Code on Administrative Offenses - only in case of violation of sanitary rules and norms concerning measures of struggle against infectious diseases. From this point of view, it seems appropriate to remove the phrase "sanitary and hygienic" from the disposition, preferring "sanitary and anti-epidemic rules and regulations" and/or adding the phrase "antiepidemic measures," thus creating opportunities for better law enforcement. Otherwise, if we leave the authorities, which have the right to draw up protocols on administrative offenses, a wide space for interpretation of Art. 44-3 of the Code of Ukraine on Administrative Offenses, this may result in increased corruption risks in the exercise of their discretionary powers, selective or erroneous application of the law, as we shall see below (Kolos \& Derkach, 2020).

In general, this administrative offense can be described as an illegal act or omission committed by an individual concerning public relations (rules and regulations) in the field of health care, in particular, those related to the quarantine of people (combating the spread of infectious diseases) (Valenko, 2020). 
From this definition we can distinguish such elements of the administrative offense as an objective party in the form of action (for example, violation of social distance over the allowable number of people in a certain area) (mass events, discos, competitions, etc.) or passenger traffic, prohibited catering establishments or other business entities, etc.) or inaction (absence of a protective mask on the face when visiting public places), the subject - a natural or official, the object - the rules and regulations for quarantine of people (Maslova, 2020).

As for the procedural features of law enforcement Art. 44-3 of the Code of Administrative Offenses, then there are three problematic issues that courts face when considering a case of administrative liability for violation of quarantine:

(i) the protocol incorrectly states the essence of the administrative offense;

(ii) it is not accompanied by sufficient evidence; and,

(iii) it concerns a person who can not be held liable for the violation of Art. 44-3 of the Code of Administrative Offenses (Nechval, 2020; Zelena, 2020).

For example, the decision of the Shevchenkivsky District Court of Kyiv from June 26, 2020, closed the proceedings in the case $n^{\circ}$ $761 / 10421 / 20$ on bringing a person to administrative responsibility under Art. 44-3 of the Code of Administrative Offenses, based on the absence in its actions of an offense. In particular, it is noted that no photographic materials were added to the protocol, and it is not clear from the check attached to the case file and which could confirm the fact of prohibited trade in coffee under quarantine, under what name and price the goods were released and whether the fact of the sale took place at all.

On the whole two factors played a role in closing the proceedings in the case $n^{\circ}$ 201/4494/20, which was pending in the Zhovtnevy District Court of Dnipro. Thus, in the decision of June 11, 2020, the court found that the protocol on an administrative offense was drawn up against a person who is not the subject of liability for violation of Art. 44-3 of the Code of Administrative Offenses, which led to the conclusion that the wording of the essence of the administrative offense is incorrect.

Regarding criminal liability for violation of quarantine, Art. 325 of the Criminal Code "Violation of sanitary rules and regulations for the prevention of infectious diseases and mass poisoning" as amended by Law $\mathrm{n}^{\circ} 530$ stated the following:

«Violation of rules and regulations established to prevent epidemic and other infectious diseases and mass non-communicable diseases and combating them, if 
such actions have caused or knowingly could cause the spread of these diseases, shall be punishable by a fine of one thousand to three thousand non-taxable minimum incomes or arrest for up to six months, or restriction of liberty for up to three years. The same acts, if they caused death or other serious consequences, are punishable by imprisonment for a term of five to eight years».

Given the above, we can identify the following elements of the crime. The object is public relations in the field of health care, in particular, rules and norms on counteracting the spread of infectious and mass noncommunicable diseases.

The objective side is the violation of these rules if such criminal acts or omissions have caused or are known to cause the spread of the above diseases.

The subject can be described as a person who, under his or her official or professional responsibilities, must ensure compliance with sanitary and anti-epidemic rules and regulations to counteract the spread of infectious and mass non-communicable diseases. Such persons include employees of public authorities, local governments, officials of enterprises, institutions and organizations, etc.

The subjective side of the crime is guilt in the form of intent or negligence (Khimchenko \& Thales, 2020).

Thus, the conditions for mitigating or aggravating criminal liability are governed by Art. 65 - 69-1 of the Criminal Code of Ukraine and, in practice, would most likely be applied in a general manner. However, the problem is that not a single case has reached the court's conviction, which we will consider further.

It is worth noting that this amendment to the criminal law was objectively and devastatingly criticized by the professional legal community immediately after it entered into force. This is due to the following factors.

First, it violates the principle of legal certainty, as it refers to a wide range of rules and regulations set out in other regulations relating to measures to combat and combat the spread of infectious and noncommunicable diseases. Given that some of the quarantine restrictions can be considered unconstitutional, as no state of emergency has been imposed (On the legal regime of the state of emergency, 2000) and criminal liability has been imposed for violating them, this would most likely be considered an inadmissible violation of human rights in a higher international court instance.

Secondly, there are reasonable suspicions that when duplicating the composition of administrative and criminal liability under Art. 44-3 of the Code of Administrative Offenses and 325 of the Criminal Code, for an administrative offense an official provides for a larger fine (from 34 
thousand to 170 thousand $\mathrm{UAH}$ ) than for a criminal one (from 17 thousand to 51 thousand $\mathrm{UAH}$ ).

Third, due to the difficulty of proving the existence of a causal link between a particular violation and the socially dangerous consequences of a case of this category, they would most likely be hopeless due to lack of evidence and inability to establish the corpus delicti, which would result in criminal proceedings.

Also, the meticulous attitude of lawyers deserved the wording "other serious consequences" in part two of the article, which in the opinion of the expert community is an evaluative judgment that would negatively affect the enforcement of this rule (Kolos \& Derkach, 2020).

Ironically, the Law "On Amendments to Certain Legislative Acts of Ukraine Aimed at Providing Additional Social and Economic Guarantees in Connection with the Spread of Coronavirus Disease (Covid-19)" $n^{\circ}$ 540-IX, Art. 325 as amended by Law ${ }^{\circ}$ 530-IX was limited to three months, until June 18, 2020, after which Art. 325 returned to its previous form, which made it impossible to apply criminal liability in the wording of the Law $\mathrm{n}^{\circ}$ 530-IX in practice for the following reason (Novikova, 2020).

According to Part 2 of Art. 4 of the Criminal Code, crime and punishment, as well as other criminal consequences of the act are determined by the law on criminal liability, which was in force at the time of the act. The exception to this rule, which is enshrined in Art. 58 of the Constitution of Ukraine and Part 1 of Art. 5 of the Criminal Code, is the retroactive effect of criminal law, which mitigates the criminal liability of a person.

Reduction of criminal liability occurs in the case of a reduction in its scope, which can occur, in particular, the abolition of the most severe of the alternative basic punishments and setting the maximum limit of the main punishment of the same type lower (Melnik \& Havronyuk, 2010).

Thus, from June 18, 2020, the punishment in the form of imprisonment as the most severe among the alternative basic punishments was abolished, and the maximum fine was reduced to UAH 1,700. As the previous version of Art. 325 of the Criminal Code provides for less severe criminal liability than the version of the Law $\mathrm{n}^{\circ} 530$-IX, there was a mitigation of criminal liability. Therefore, from June 18, 2020, this wording has a retroactive effect on crimes committed during the wording of the Law $\mathrm{n}^{\circ} 530-\mathrm{IX}$, i.e. during March 17, 2020-June 17, 2020.

In this regard, the fine and imprisonment provided for in Art. 325 as amended by Law $\mathrm{n}^{\circ}$ 530-IX will never be applied to violators.

We will note that because of the legal nuance connected with duration of action of the norm, criminal liability according to Art. 325 of the Criminal Code will be more profitable to bear from an economic point of view than 
administrative one under Art. 44-3 of the Code of Administrative Offenses, as the size of the sanctions for the latter, is much larger, which seems a bit unexpected when comparing the severity of administrative and criminal laws (Yasynska, 2020).

In our opinion, legal inaccuracies could be eliminated by drawing up an article regulating criminal liability for violating quarantine rules, as follows: "Violation of rules and regulations established to prevent the spread of acute respiratory disease Covid-19 caused by SARS-CoV-2, a person with a confirmed diagnosis of Covid-19, if such actions have caused or may have caused the spread of the disease, shall be punished by a fine of three to ten thousand non-taxable minimum incomes or imprisonment for a term of five to eight years.

In total, the position of the legislator to use toughening of legal responsibility as a way to motivate the population to comply with quarantine measures is understandable, but it was carried out extremely inconsistently. For three months the law enforcement agencies were forced to draw up protocols on an administrative offense and initiate criminal cases, which will be lost in court. Ultimately, we consider this an ineffective way of spending taxpayers' funds and a demotivating situation for law enforcement agencies.

The optimal solution would be to establish a small amount of money for administrative fines and direct organizational forces for impeccable execution. The population would quickly spread the news of an imminent fine for violating quarantine, and this money would replenish the fund to fight the infection. As for the criminal prosecution - to change the subjective side of the crime only to intent, which excludes criminal liability for a person who, through negligence, infected someone. This would allow us to focus only on really dangerous people because the deliberate spread of infection is already bioterrorism. And of course, we are against the "rollback" of the law after the quarantine, which neutralizes all actions to educate the correct model of behavior among the population. Anyone who committed an administrative offense or crime during quarantine should be punished accordingly.

\section{CONCLUSIONS}

As a result of the study, the following conclusions can be drawn.

1. All over the world, countries have applied administrative and criminal penalties to comply with quarantine measures, but the proportionality of these actions and the practice of law enforcement jeopardize human rights and freedoms. The question of proportionality is 
debatable, however, by analogy with other infections in mortality, the measures taken are excessive. All of this is extremely worrying and confirms the need for research in the health and legal fields to develop optimal solutions for governments in possible future epidemics.

2. Under the influence of the spread of the epidemic of acute respiratory disease Covid-19, the legislation of Ukraine faced a serious dilemma of preserving the balance of human rights and protecting the public interest. To create minimum preventive conditions, as well as to regulate the issue of liability for violations of quarantine measures, several legislative changes were adopted, in particular, in the areas of administrative and criminal law. Balancing between freedoms and restrictions, caring for the welfare of citizens, the leadership of our country has taken measures that are more correlated with the experience of foreign countries, which also introduced sanctions for violations of quarantine, which significantly exceed the solvency of citizens. Such sanctions are intended to deter individuals from violating quarantine, that is, they are preventive in nature.

3. There are certain practical problems related to the enforcement by the authorities of the rules governing liability for breach of quarantine. These discrepancies consist in a certain duplication of Arts. 44-3 of the Code of Administrative Offenses and 325 of the Criminal Code, the ratio of norms 42 and 44-3 of the Code of Administrative Offenses as general and special one, correct drawing up of protocols and related further court proceedings on administrative offenses.

4. Given the above, the scientific and expert community has been largely skeptical of innovations in administrative and criminal law relating to liability for breach of quarantine conditions. Taking into account the duration of the sanction, which was mentioned in the "coronavirus" version of the Criminal Code, as well as the range of shortcomings associated with its enforcement, there is a reasonable cause to believe that the legislator deliberately introduced such an imperfect rule in criminal law to create the corresponding social-psychological effect, but without serious intention of its application that is caused by contradiction of its legal nature.

5. Among the shortcomings of criminal liability under Art. 325 of the Criminal Code in the wording of the Law $n^{\circ}$ 530-IX can be called inconsistency of the norm with the principle of legal certainty, duplication of the disposition of the sanction for violation of quarantine of people, which is specified in Art. 44-3 of the Code of Administrative Offenses, and a complex mechanism for proving the causal link between the violation and the consequences, which in turn would lead to the closure of criminal cases on the grounds of impossibility to establish the corpus delicti. 
6. In some ways, it can be argued that the problems associated with the legal regulation of criminal liability for violation of quarantine restrictions have disappeared by themselves due to the expiration of the norm of Art. 325 of the Criminal Code as amended by Law n ${ }^{\circ}$ 530-IX, which is a positive factor, but, at the same time, it raises new questions to the legislative branch of government. The abolition of administrative and criminal liability for offenses during quarantine is a gross mistake of the legislator, which leveled the layer of work of law enforcement agencies and negatively affected the legal education of the population. It was necessary to act gently, but rigorously and consistently.

7. Regarding the improvement of administrative liability for violation of quarantine conditions, it is proposed to formulate the disposition of Art. 44-3 of the Code of Administrative Offenses in such a way as to prevent duplication of its content with other legal norms, which will promote compliance with the principle of legal certainty and avoid unjustified expansion of discretionary powers of regulatory authorities or local governments and related corruption risks.

8. Regarding the avoidance of mistakes made by the legislator in the introduction of criminal liability for violation of quarantine, it is proposed to supplement the Criminal Code of Art. 325-1 "Violation of the rules and regulations established to prevent the spread of acute respiratory disease Covid-19 caused by SARS-CoV-2 virus, by a person with a confirmed diagnosis of Covid-19."

\section{REFERENCES}

Alcoba, N. (2020). Breaking coronavirus quarantine in Argentina could mean jail time. Al Jazeera. In https://www.aljazeera.com/news/2020/03/breaking-coronavirusquarantine-argentina-jail-time-200318160931683.html.

Arakelyan, M. R. (2020). Human rights activities in a pandemic. Legal life of modern Ukraine, 3, 3-6.

Chizhik, E. (2020). Covid-19: How quarantine violators are fined in Ukraine and around the world. In https://zn.ua/ukr/WORLD/covid-19-yak-shtrafuyut-porushnikivkarantinu-v-ukrayini-ta-sviti-341906_.html.

Convention for the Protection of Human Rights and Fundamental Freedoms as amended by Protocols $n^{\circ} 11$ and 14 (1950).

Dmytruk, O. (2020). What are the fines for violating quarantine in the world-infographics. The Village Ukraine. In https://www.the-village.com.ua/village/city/citynews/295397-yaki-shtrafi-za-porushennya-karantinu-u-sviti-infografika. 
Dovgal, E. (2020). Criminal liability for violation of quarantine rules. Liga- Blog. In https://blog.liga.net/user/edovhal/article/kriminalna-vidpovidalnist-zaporushennya-pravil-karantinu.

European Court of Human Rights. (2020). Derogation in time of emergency. In https://www.echr.coe.int/Documents/FS_Derogation_ENG.pdf.

Khimchenko, S. A. \& Thales, O. G. (2020). Criminal liability for the spread of coronavirus disease (Covid-19). Legal Life of Modern Ukraine, 3, 149-151.

Klochkov, V. \& Starosta, I. (2020). Thin ice: administrative or criminal liability for violation of quarantine? Jurliga. In https://jurliga.ligazakon.net/ua/analitycs/194042_tonkiy-ld-admnstrativna-chikrimnalna-vdpovdalnst-za-porushennya-karantinu.

Kolos, Y. \& Derkach, D. (2020). Quarantine: new fines and liability for business. Vasyl Kisil. In https://vkp.ua/publication/karantin-novi-shtrafi-ta-vidpovidalnist-dlyabiznesu.

Kuzembayev, O. S. (2020). Normative bases of criminal liability in Ukraine for infection with coronavirus SARS-CoV-2 (Covid-19). Legal life of modern Ukraine, 3, 129-132.

Lisova, Y. (2020). What is the responsibility for violating quarantine? An explanation of the Public Center for Justice. Public Space. In https://www.prostir.ua/?news=yaka-vidpovidalnist-za-porushennya-karantynurozyasnennya-hromadskoho-tsentru-pravosuddya.

Londoño Martínez, F. (2020). Criminal Liability for Quarantine Breakers? Critical Review of Articles 318 And 318 bis of the Chilean Penal Code. Associazione "Progetto Giustizia Penale." In https://www.criminaljusticenetwork.eu/en/post/criminal-liability-forquarantine-breakers-critical-review-of-articles-318-and-318-bis-of-the-chileanpenal-code-new-law-no-21240-more-micro-than-macro.

Maslova, Y. I. (2020). Administrative liability for violation of quarantine measures in a pandemic of coronavirus infection. Legal life of modern Ukraine, 2, 52-54.

Melnik, M. \& Havronyuk, M. (2010). Scientific and practical commentary on the Criminal Code of Ukraine. Kyiv: Legal opinion.

Mervosh, S., Lu, D. \& Swales, V. (2020). See Which States and Cities Have Told Residents to Stay at Home. The New York Times. In https://www.nytimes.com/interactive/2020/us/coronavirus-stay-at-homeorder.html.

Navrotska, O. (2020). How are people punished in different countries for violating quarantine? In-Poland. In https://inpoland.net.pl/novosti/yak-karayut-lyudejj-uriznikh-kra\%D1\%97nakh-za-porushennya-karantinu/.

Nechval, Ya. V. (2020). How to protect yourself from a fine for violating the rules of quarantine (Article 44-3 of the Code of Administrative Offenses). Protocol. In https://protocol.ua/ru/yak_zahistitis_vid_shtrafu_za_porushennya_pravil_karant inu_(st_44_3_kupap)/. 
Novikova, M. (2020). How the Coronavirus ended for the Criminal Code. Legal newspaper online. In https://yur-gazeta.com/publications/practice/kriminalnepravo-ta-proces/yak-dlya-kriminalnogo-kodeksu-koronaviruszakinchivsya.html.

Perepadia, O. (2020). Coronavirus: what is the penalty for violating the rules of quarantine? Deutsche Welle. In https://p.dw.com/p/3aIID.

Ron, O. (2020). 86 criminal investigations opened due to quarantine violations. The Jerusalem Post. In https://www.jpost.com/Israel-News/Haredi-wedding-breaksHealth-Ministry-guidelines-621371.

Sun, N. \& Zilli, L. (2020). Covid-19 Symposium: The Use of Criminal Sanctions in Covid-19 Responses-Enforcement of Public Health Measures. Opinio Juris. In http://opiniojuris.org/2020/04/03/covid-19-symposium-the-use-of-criminalsanctions-in-covid-19-responses-enforcement-of-public-health-measures-partii/.

Tondo, L. (2020). Italy charges more than 40,000 people with violating lockdown. The Guardian. In https://www.theguardian.com/world/2020/mar/18/italy-chargesmore-than-40000-people-violating-lockdown-coronavirus.

Tulyakov, V. O. (2020). The meanings of criminal law in an era of instability. Legal Life of Modern Ukraine, 3, 86-88.

Turak, N. (2020). UAE bans its citizens from traveling, bars entry to residency visa holders for two weeks, suspends work permit issuance. $C N B C$. In https://www.cnbc.com/2020/03/18/coronavirus-uae-bans-citizens-fromtraveling-mandates-14-day-quarantine-for-entrants.html.

Ukraine. (1984). Code of Ukraine on Administrative Offenses: Law. In https://zakon.rada.gov.ua/laws/show/80731-10.

Ukraine. (1994). On Ensuring Sanitary and Epidemic Welfare of the Population: Law 4004-XII. In https://zakon.rada.gov.ua/laws/show/4004-12\#Text.

Ukraine. (1995). Ministry of Health of Ukraine. On approval of the List of especially dangerous infectious, parasitic human diseases and carriers of pathogens of these diseases: Order 133. In https://zakon.rada.gov.ua/rada/show/v013328295.

Ukraine. (1996). Constitution of Ukraine. In https://zakon.rada.gov.ua/laws/show/254\%D0\%BA/96-\%D0\%B2\%D1\%80.

Ukraine. (2000). On the legal regime of the state of emergency: Law 1550-III. In https://zakon.rada.gov.ua/laws/show/1550-14\#Text.

Ukraine. (2002). Criminal Code of Ukraine. In https://zakon.rada.gov.ua/laws/show/234114/conv\#n19.

Ukraine. (2020). On Amendments to Certain Legislative Acts of Ukraine Aimed at Preventing the Occurrence and Spread of Coronavirus Disease (Covid-19): Law 530-IX. In https://zakon.rada.gov.ua/laws/show/530-20\#Text.

Ukraine. (2020). On protection of the population from infectious diseases: Law 1645-III. In https://zakon.rada.gov.ua/laws/show/1645-14. 
Ukraine. (2020). Shevchenkivskyi District Court of the city of Kyiv. Resolution 761/10421/20. In http://reyestr.court.gov.ua/Review/90252776.

Ukraine. (2020). Zhovtnevyi District Court of the city of Dnipro. Resolution 201/4494/20. In http://reyestr.court.gov.ua/Review/90209353.

Ukraine. Cabinet of Ministers. (2020). On prevention of the spread of coronavirus Covid19 on the territory of Ukraine: Resolution 211. In https://www.kmu.gov.ua/npas/pro-vnesennya-zmin-do-postanovi-kabinetuministriv-ukrm020420ayini-vid-11-bereznya-2020-r-211.

Ukraine. Cabinet of Ministers. (2020). On the establishment of quarantine in order to prevent the spread of acute respiratory disease Covid-19 caused by coronavirus SARS-CoV-2 in Ukraine: Resolution 392. In https://zakon.rada.gov.ua/laws/show/392-2020-\%D0\%BF\#Text.

Ukrinform. (2020). The whole world is in quarantine. In https://www.ukrinform.ua/rubricworld/2898486-ves-svit-na-karantini.html.

United Nations. (1948). Universal Declaration of Human Rights. In https://www.un.org/en/universal-declaration-human-rights/.

United States of America (2001). Uniting and strengthening America by providing appropriate tools required to intercept and obstruct terrorism (USA patriot act). In https://www.congress.gov/107/plaws/publ56/PLAW-107publ56.pdf.

American Association for the International Commission of Jurists. (1985). Siracusa Principles on the Limitation and Derogation of Provisions in the International Covenant on Civil and Political Rights. In https://www.icj.org/wpcontent/uploads/1984/07/Siracusa-principles-ICCPR-legal-submission-1985eng.pdf.

Valenko, A. (2020). Liability for violation of quarantine conditions are subject to all persons - regardless of the presence of coronavirus. Legal newspaper online. In https://yur-gazeta.com/golovna/vidpovidalnosti-za-porushennya-umovkarantinu-pidlyagayut-vsi-osobi--nezalezhno-vid-nayavnosti-v-nih.html.

Word and Deed. (2020). How to fine for violating quarantine rules in Ukraine and other countries. In https://www.slovoidilo.ua/2020/03/17/infografika/suspilstvo/yakshtrafuyut-porushennya-pravyl-karantynu-ukrayini-ta-inshyx-derzhavax.

World Health Organization. (2017). Ethics guidance for the implementation of the End TB Strategy. In https:/www.who.int/tb/publications/2017/ethics-guidance/en/.

Yasynska, M. (2020). Fines for quarantine: the first case-law. Pravo. In https://pravo.ua/shtrafi-za-porushennja-karantinu-persha-sudova-praktika/.

Zelena, R. (2020). Court vs. quarantine rules. Liga Zakon. In https://uz.ligazakon.ua/ua/magazine_article/EA013669. 